GC-MS ANALYSIS OF METHANOLIC AND N-HEXANE EXTRACTS FROM BUTTERFLY PEA FLOWERS (Clitoria ternatea L.)

\title{
ANALISIS GC-MS EKSTRAK METANOL DAN N-HEKSAN DARI BUNGA TELANG (Clitoria ternatea $\mathrm{L}$.)
}

\author{
Nurul Qalbiyyah Ma'ruf 1)*, Irma Antasionasti ${ }^{1)}$, Fatimawali ${ }^{1)}$, Trina Tallei ${ }^{2)}$ \\ ${ }^{1)}$ Program Studi Farmasi FMIPA UNSRAT Manado, 95115 \\ ${ }^{2)}$ Program Studi Biologi FMIPA UNSRAT Manado, 95115 \\ *nurulmaruf07@gmail.com
}

\begin{abstract}
The butterfly pea flower (Clitoria ternatea L.) is a flower can grow as an ornamental plant or a wild plant with a single purple petal. This study aims to analyze the phytochemical compounds from butterfly pea flower. The method used is the extraction of dried powder of butterfly pea flowers using methanol and nhexane solvent then analyzed using GC-MS. The analysis showed that there were 48 possible compounds detected in the methanol extract and 18 possible compounds detected in the $n$-hexane extract of butterfly pea flower. The compound from the methanol extract which had the highest peak were d-Mannose, $d$-Glycero-d ido-heptose, and Galacto-heptulose. While the compounds from the n-hexane extract that had the highest peak were Longipinocarvone, Acetic acid, 3-hydroxy-6-isopropenyl-4,8a-dimethyl-1,2,3,5,6,7,8,8aoctahydronaphthalen-2 -yl ester, and 10-12-Pentacosadiynoic acid.
\end{abstract}

Keywords $\quad$ : Clitoria ternatea L, butterfly pea flower, GC-MS

\begin{abstract}
ABSTRAK
Bunga Telang (Clitoria ternatea L.) merupakan bunga yang dapat tumbuh sebagai tanaman hias maupun tanaman liar dengan kelopak tunggal berwarna ungu. Penelitian ini bertujuan untuk menganalisis senyawa fitokimia dari bunga Telang. Metode yang digunakan yaitu ekstraksi serbuk kering bunga Telang menggunakan pelarut metanol dan n-heksan kemudian dianalisis menggunakan $G C-M S$. Hasil analisis menunjukkan bahwa terdapat 48 kemungkinan senyawa yang terdeteksi dalam ekstrak metanol dan 18 kemungkinan senyawa yang terdeteksi dalam ekstrak n-heksan bunga Telang. Senyawa dari ekstrak metanol yang memiliki puncak tertinggi yaitu d-Mannose, d-Glycero-d ido- heptose, dan Galacto-heptulose. Sedangkan senyawa dari ekstrak n-heksan yang memiliki puncak tertinggi yaitu Longipinocarvone, Acetic acid, 3-hydroxy-6-isopropenyl-4,8a-dimethyl-1,2,3,5,6,7,8,8a-octahydronaphthalen-2-yl ester, dan 10-12Pentacosadiynoic acid.
\end{abstract}

Kata kunci $\quad$ : Clitoria ternatea $\mathrm{L}$, kembang Telang, $G C-M S$ 


\section{PENDAHULUAN}

Bunga Telang (Clitoria ternatea L.) merupakan bunga majemuk, terbentuk pada ketiak daun, memiliki tangkai silindri, panjangnya kurang lebih $1,5 \mathrm{~cm}$, memiliki kelopak berbentuk corong, mahkota berbentuk kupu-kupu dan berwarna biru, tangkai benang sari berlekatan membentuk tabung, kepala sari bulat, tangkai putik silindris, dan kepala putik bulat (Hartono, dkk. 2013). Pada bunga telang juga terkandung flobatanin, karbohidrat, triterpenoid, flavanol glikosida, protein, alkaloid, antrakuinon, stigmasit 4-ena-3,6 dion, minyak volatil dan steroid. Komposisi asam lemak dalam bunga telang meliputi asam palmitat, stearat, oleat lonoleat, dan linolenat (Budiasih, 2017). Hasil penelitian Chayaratanasin (2015), menunjukkan kandungan fenolat total, flavonoid dan antosianin dalam bunga telang sebesar $53 \pm 0,34 \mathrm{mg}$ asam galat setara/g ekstrak kering, 11,2 $\pm 0,33 \mathrm{mg}$ katekin setara/g ekstrak kering, dan 1,46 $\pm 0,04 \mathrm{mg}$ yang setara sianidin-3-glukosida/g ekstrak kering.

Gass Chromatography and Mass Spectroscopy $(G C-M S)$ merupakan teknik analisis yang menggunakan dua metode analisis yaitu kromatografi gas dan spektrometri massa. Paduan keduanya dapat menghasilkan data yang lebih akurat dalam pengidentifikasian senyawa yang dilengakapi dengan struktur molekulnya (Rubiyanto, 2017).

Penelitian ini bertujuan untuk menganalisis senyawa fitokimia dari ekstrak bunga Telang yang dilarutkan dalam pelarut metanol dan n-heksan menggunakan metode $G C$ $M S$. Pelarut yang digunakan dalam proses ekstraksi sangat menentukan terhadap komponenkomponen fitokimia yang terekstrak. Penggunaan pelarut metanol dan n-heksan didasarkan tingkat kepolarannya dari paling polar dan non polar.

\section{METODOLOGI PENELITIAN \\ Waktu dan Tempat Penelitian}

Penelitian dilakukan di Universitas

Gadjah Mada Yogyakarta untuk uji GC-MS dan Fakultas Matematika dan Ilmu Pengetahuan Alam Universitas Sam Ratulangi Manado untuk proses analisis data hasil uji $G C-M S$ selama bulan Oktober 2020 hingga Januari 2021.

\section{Alat dan Bahan}

Alat

Blender, alumunium foil, alat-alat gelas, wadah, ayakan mess 100 , oven, batang pengaduk, kromatografi gas dan spektrometri massa. Perangkat keras laptop Lenovo-Ideapad 3i dengan spesifikasi Intel ${ }^{\circledR}$ Core I3 Gen10, CPU(@1,2GHz TurboBoost up to 3,5GHz), RAM (Random Access Memory) 4 gigabyte dan Garphic Card (Intel UHD Graphics G1). Laptop terhubung dengan internet.

\section{Bahan}

Bahan-bahan yang digunakan dalam penelitian ini antara lain bunga Telang (Clitoria ternatea L.), pelarut metanol dan pelarut $\mathrm{n}$ heksan.

\section{Prosedur}

Sampel yang digunakan yaitu bunga Telang yang diperoleh dari daerah Jawa Barat. Bunga tersebut kemudian dibersihkan dari pengotor dan dicuci di bawah air mengalir sampai bersih. Setelah itu sampel dikeringkan dengan cara di oven dengan suhu $40^{\circ} \mathrm{C}$. Selanjutnya sampel yang telah kering dihaluskan sampai menjadi serbuk. Serbuk kemudian diayak menggunakan ayakan mesh 100 sehingga didapatkan serbuk halus dan homogen. Pembuatan ekstrak Bunga Telang menggunakan metode perendaman atau yang lebih dikenal dengan maserasi, kemudian dimasukkan ke dalam micro tube, lalu di-vortex dan disentrifugasi. Supernatan yang terbentuk digunakan untuk analisis $G C-M S$. Waktu diatur selama 60 menit dengan suhu injektor $260^{\circ} \mathrm{C}$, detektor $250^{\circ}$, dan kolom $325^{\circ} \mathrm{C}$. Gas helium digunakan sebagai pembawa laju aliran kosntan $1 \mathrm{ml} /$ menit. Proses identifikasi menggunakan alat GC-MS mengahasilkan daftar senyawa yang di dalamnya terdapat campuran gas dan berat molekul masingmasing senyawa yang disajikan dalam bentuk kromatogram.

\section{HASIL DAN PEMBAHASAN Analisis $G C$-MS}

Kromatografi gas dan spektrometri massa menunjukkan kromatogram dari ekstrak metanol dan n-heksan bunga Telang (Gambar 1 dan 2). Penggunaan kromatografi gas dipadukan dengan spektrometri massa merupakan instrumen yang digunakan untuk pemisahan dan identifikasi. Kromatografi gas mampu membaca senyawa dengan konsentrasi terendah, sehingga metabolit sekunder dalam tanaman dapat teridentifikasi dengan hasil berupa kromatogram dan spektrum massa. (Al-Rubaye et al., 2017). Hasil analisis menunjukkan bahwa terdapat 48 kemungkinan komponen senyawa yang berhasil diekstraksi dari 
pelarut metanol dan 18 kemungkinan komponen senyawa dari ekstrak n-heksan bunga Telang dengan Similarity Index (SI) berbeda (Tabel 1 dan 2).

Tabel 1 dan 2 menunjukkan komponen senyawa terbanyak bunga Telang dalam ekstrak metanol terletak pada peak 7 dengan presentase kadar (retention area) yaitu $75.41 \%$. Ketiga senyawa tersebut adalah $d$-Mannose, $d$-Glycero-d ido- heptose, dan Galacto-heptulose. Sedangkan, untuk ekstrak n-heksan bunga Telang memiliki komponen senyawa terbanyak pada peak 4 dengan presentase

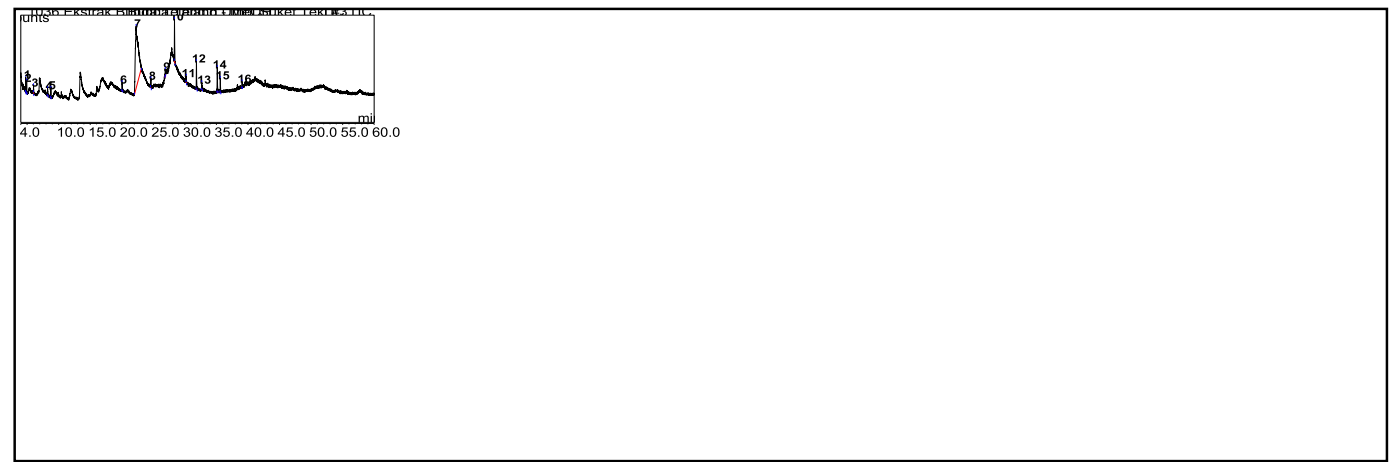

Gambar 1. Hasil Kromatogram GC-MS dari Ekstrak Metanol Bunga Telang

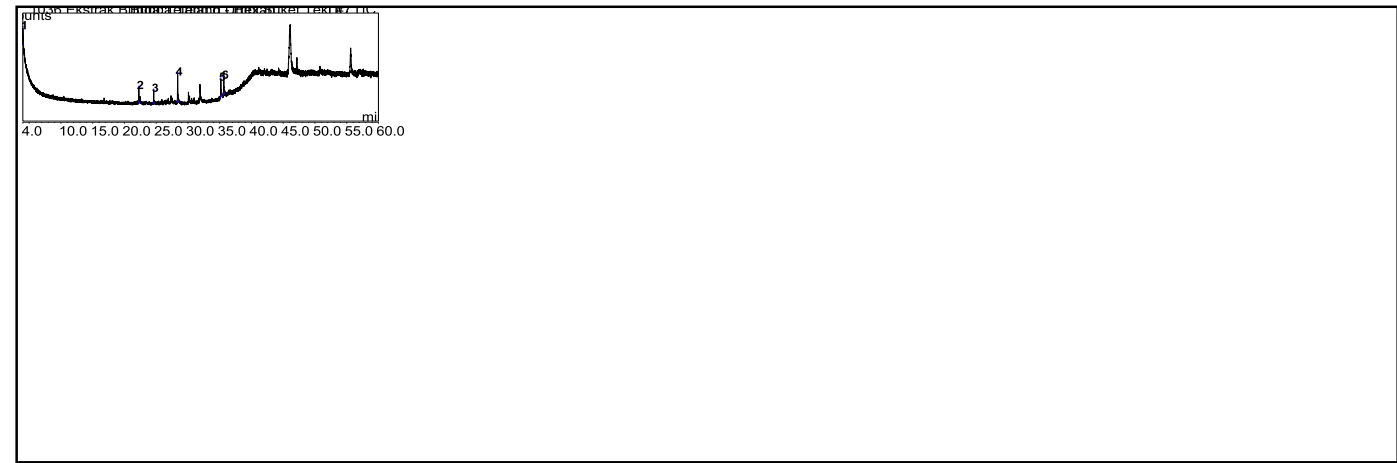

Gambar 2. Hasil Kromatogram GC-MS dari Ekstrak N-Heksan Bunga Telang

Tabel 1. Senyawa yang diidentifikasi menggunakan analisis GC-MS dari dari ekstrak metanol bunga Telang

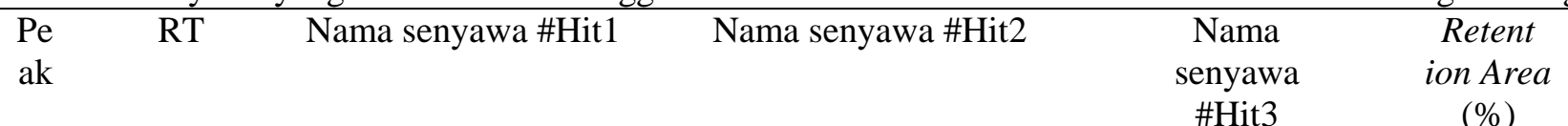

\begin{tabular}{llllll}
\hline 1 & 4.79 & $\begin{array}{l}\text { 1,3,5-Pentanetriol, 3- } \\
\text { methyl- }\end{array}$ & $\begin{array}{l}\text { l-Nitro-2 } \\
\text { acetamido-1,2- } \\
\text { dideoxy-d- } \\
\text { mannitol }\end{array}$ & $\begin{array}{l}\text { Mannosami } \\
\text { ne } \\
\text { (karbohidrat }\end{array}$ & 1.22 \\
\hline 2 & 4.93 & $\begin{array}{l}\text { Acetic acid, } \\
2,2^{\prime}[\text { oxybis(2,1eth } \\
\text { anediyloxy)]bis- }\end{array}$ & $\begin{array}{c}\text { Tetraacetyl-d-xylonic } \\
\text { nitrile }\end{array}$ & $\begin{array}{c}\text { l-Gala-l-ido- } \\
\text { octose }\end{array}$ & 1.00 \\
& & & & \\
\hline 3 & 6.02 & $\begin{array}{l}\text { l-Nitro-2 } \\
\text { acetamido-1,2- } \\
\text { dideoxy-d- } \\
\text { mannitol }\end{array}$ & $\begin{array}{c}\text { Tetraacetyl-d-xylonic } \\
\text { nitrile }\end{array}$ & $\begin{array}{c}\text { d-Glycero-d-ido- } \\
\text { heptose }\end{array}$ & 0.66 \\
& & & & \\
\hline
\end{tabular}


PHARMACON-PROGRAM STUDI FARMASI, FMIPA, UNIVERSITAS SAM RATULANGI,

Volume 10 Nomor 2 Mei 2021

\begin{tabular}{|c|c|c|c|c|c|}
\hline 4 & 8.25 & DL-Arabinose & Desulphosinigrin & $\begin{array}{c}a-D \\
\text { Galactopyranose, } \\
2 \text { (acetylamin)-2- } \\
\text { deoxy- }\end{array}$ & 1.23 \\
\hline 5 & 8.76 & $\begin{array}{l}\text { 1-Nitro-2-acetamido- } \\
\text { 1,2-dideoxy-d-mannitol }\end{array}$ & Isosorbide Dinitrate & Chlorozotocin & 0.90 \\
\hline 6 & 20.04 & $\begin{array}{c}d \text {-Gala-l-ido octonic } \\
\text { amide }\end{array}$ & $\begin{array}{l}\text { 2-Myristynoyl } \\
\text { pantetheine }\end{array}$ & $\begin{array}{l}\text { l-Gala-l-ido } \\
\text { octonic lactone }\end{array}$ & 1.28 \\
\hline 7 & 22.27 & d-Mannose & $\begin{array}{l}\text { d-Glycero-d ido- } \\
\text { heptose }\end{array}$ & $\begin{array}{l}\text { Galacto- } \\
\text { heptulose }\end{array}$ & 75.41 \\
\hline 8 & 24.62 & l-Gala-l-ido-octose & $\begin{array}{l}\text { Pterin-6 carboxylic } \\
\text { acid }\end{array}$ & $\begin{array}{l}\text { Tetraacetyl- } d- \\
x y l o n i c \text { nitrile }\end{array}$ & 1.04 \\
\hline 9 & 26.91 & $\begin{array}{l}\text { d-Gala-l-ido-octonic } \\
\text { amide }\end{array}$ & $\begin{array}{l}\text { [1,1'-Bicyclopropyl]- } \\
\text { 2-octanoic acid, 2'- } \\
\text { hexyl-, methyl ester }\end{array}$ & $\begin{array}{l}\text { l-Gala-l-ido- } \\
\text { octose }\end{array}$ & 0.70 \\
\hline 10 & 28.36 & $\begin{array}{c}\text { Acetic acid, 3-hydroxy- } \\
\text { 6-isopropenyl-4,8a- } \\
\text { dimethyl- } \\
\text { 1,2,3,5,6,7,8,8a- } \\
\text { octahydronaphthalen-2- } \\
\text { yl ester }\end{array}$ & $\begin{array}{c}\text { 12,15-Octadecadiynoic } \\
\text { acid, methyl ester }\end{array}$ & Ambrosin & 5.21 \\
\hline 11 & 30.22 & Desulphosinigrin & $\begin{array}{l}d \text {-Gala-l-ido-octonic } \\
\text { amide }\end{array}$ & $\begin{array}{l}\text { 2-Myristynoyl } \\
\text { pantetheine }\end{array}$ & 0.80 \\
\hline 12 & 31.84 & $\begin{array}{l}\text { Hexadecanoic acid, } \\
\text { methyl ester }\end{array}$ & $\begin{array}{l}\text { Pentadecanoic acid, } 14- \\
\text { methyl-, methyl ester }\end{array}$ & $\begin{array}{c}\text { Cyclopropanebuta } \\
\text { noic acid, 2-[[2- } \\
\text { [[2-[(2- } \\
\text { pentylcyclopropyl }) \\
\text { methyl]cyclopropy } \\
\text { l]methyl]cyclopro } \\
\text { pyl]methyl]-, } \\
\text { methyl ester }\end{array}$ & 3.70 \\
\hline 13 & 32.68 & Desulphosinigrin & $\begin{array}{c}\text { [1,1'-Bicyclopropyl]-2- } \\
\text { octanoic acid, 2'-hexyl-, } \\
\text { methyl ester }\end{array}$ & $\begin{array}{l}\text { Ethyl iso- } \\
\text { allocholate }\end{array}$ & 1.57 \\
\hline 14 & 35.14 & $\begin{array}{c}\text { 10-Octadecenoic acid, } \\
\text { methyl ester }\end{array}$ & $\begin{array}{c}\text { 11-Octadecenoic acid, } \\
\text { methyl ester }\end{array}$ & $\begin{array}{l}\text { 16-Octadecenoic } \\
\text { acid, methyl ester }\end{array}$ & 3.01 \\
\hline
\end{tabular}




\begin{tabular}{|c|c|c|c|c|c|}
\hline 15 & 35.61 & $\begin{array}{l}\text { Heptadecanoic acid, 16- } \\
\text { methyl-, methyl ester }\end{array}$ & $\begin{array}{c}\text { Cyclopropanebutanoic } \\
\text { acid, 2-[[2-[[2-[(2- } \\
\text { pentylcyclopropyl)methy } \\
\text { l]cyclopropyl]methyl]cy } \\
\text { clopropyl]methyl]-, } \\
\text { methyl ester }\end{array}$ & $\begin{array}{l}\text { Cyclopropanedod } \\
\text { ecanoic acid, 2- } \\
\text { octyl-, methyl } \\
\text { ester }\end{array}$ & 1.68 \\
\hline 16 & 39.07 & Ethyl iso-allocholate & $\begin{array}{c}\text { Cyclopropanedodecanoi } \\
\text { c acid, 2-octyl-, methyl } \\
\text { ester }\end{array}$ & $\begin{array}{c}\text { Ergosta-5,22- } \\
\text { dien-3-ol, acetate, } \\
(3 \beta, 22 E)-\end{array}$ & 0.65 \\
\hline
\end{tabular}

Tabel 2. Senyawa yang diidentifikasi menggunakan analisis $G C-M S$ dari dari ekstrak n-heksan bunga Telang

\begin{tabular}{|c|c|c|c|c|c|}
\hline $\begin{array}{l}\mathrm{Pe} \\
\mathrm{ak}\end{array}$ & RT & Nama senyawa \#Hit1 & Nama senyawa \#Hit2 & $\begin{array}{l}\text { Nama } \\
\text { senyawa } \\
\text { \#Hit3 }\end{array}$ & $\begin{array}{l}\text { Retent } \\
\text { ion Area } \\
(\%)\end{array}$ \\
\hline 1 & 4.01 & 2-Ethyl-oxetane & $\begin{array}{l}\text { 1,6-Anhydro-2,4- } \\
\text { dideoxy- } \beta \text {-D-ribo- } \\
\text { hexopyranose }\end{array}$ & $\begin{array}{c}1- \\
\text { Hexanamin } \\
e, 3,5,5- \\
\text { trimethyl- }\end{array}$ & 9.07 \\
\hline 2 & 22.27 & $\begin{array}{c}\text { Butyl 6,9,12,15- } \\
\text { octadecatetraeno } \\
\text { ate }\end{array}$ & Methyl stearidonate & $\begin{array}{l}\text { 1-Hexanamine, } \\
\text { 3,5,5-trimethyl- }\end{array}$ & 10.47 \\
\hline 3 & 24.62 & $\begin{array}{c}\text { Caryophyllene } \\
\text { oxide }\end{array}$ & $\begin{array}{c}\text { Z,Z,Z-4,6,9- } \\
\text { Nonadecatriene }\end{array}$ & $\begin{array}{c}\text { 10-12- } \\
\text { Pentacosadiynoic } \\
\text { acid }\end{array}$ & 10.22 \\
\hline 4 & 28.37 & Longipinocarvone & $\begin{array}{c}\text { Acetic acid, 3-hydroxy- } \\
\text { 6-isopropenyl-4,8a- } \\
\text { dimethyl- } \\
\text { 1,2,3,5,6,7,8,8a- } \\
\text { octahydronaphthalen-2- } \\
\text { yl ester }\end{array}$ & $\begin{array}{c}10-12- \\
\text { Pentacosadiynoic } \\
\text { acid }\end{array}$ & 34.14 \\
\hline 5 & 35.18 & $\begin{array}{c}\text { 11-Octadecenoic acid } \\
\text { methyl ester }\end{array}$ & $\begin{array}{c}\text { 10-Octadecenoic acid, } \\
\text { methyl ester }\end{array}$ & $\begin{array}{l}\text { 9-Octadecenoic } \\
\text { acid (Z)-, 2- } \\
\text { hydroxy-1- } \\
\text { (hydroxymethyl)et } \\
\text { hyl ester }\end{array}$ & 20.25 \\
\hline 6 & 35.64 & $\begin{array}{c}\text { Heptadecanoic acid, } \\
\text { 9-methyl-, methyl } \\
\text { ester }\end{array}$ & $\begin{array}{c}\text { Cyclopropanedodecanoi } \\
\text { c acid, 2-octyl-, methyl } \\
\text { ester }\end{array}$ & $\begin{array}{l}\text { Cyclopropanepent } \\
\text { anoic acid, 2- } \\
\text { undecyl-, methyl } \\
\text { ester, trans- }\end{array}$ & 15.84 \\
\hline
\end{tabular}

Ketiga senyawa pada peak 4 yaitu Longipinocarvone, Acetic acid, 3-hydroxy-6isopropenyl-4,8a-dimethyl-1,2,3,5,6,7,8,8aoctahydronaphthalen-2-yl ester, dan 10-12Pentacosadiynoic acid. Metabolit sekunder yang terkandung pada bunga Telang berdasarkan hasil diindentifikasi dengan $G C-M S$ yaitu golongan karbohidrat, terpenoid, asam lemak, antosianin dan flavonoid.

Menurut penelitian Ezzudin dan Rabeta (2018) senyawa utama pada bunga Telang yaitu flavonoid, antosianin, alkaloid, tertanins, saponin, tanin, taraxerol, dan taraxerone. Menurut (AlSanafi, 2016) bunga Telang mengandung senyawa tanin, saponin, triterpenoid, flavonoid, alkaloid, fenol, flavanol glikosida, antrakuinon, antosianin, minyak esensial, protein dan karbahidrat yang memiliki manfaat untuk kesehatan tubuh.

Berdasarkan tinjauan fiokimia, bunga Telang dapat bermanfaat untuk kesehatan tubuh karena mengandung bahan aktif yang memiliki potensi farmakologi. Potensi farmakologi bunga 
Telang sebagai antioksidan, antibakteri, anti inflamasi, analgesik, antikanker, antihistamin, imunomodulator dan potensi yang berperan dalam susunan saraf pusat (Budiasih, 2017).

\section{KESIMPULAN}

Hasil analisis $G C-M S$ terdapat 48 komponen senyawa yang berhasil di ekstraksi dari pelarut metanol dan 18 komponen senyawa dari ekstrak n-heksan bunga Telang (Clitoria ternatea L.) yang memiliki Similarity Index (SI) yang berbeda. Metabolit sekunder yang terkandung didalamnya yaitu karbohidrat, terpenoid, asam lemak, dan flavonoid.

\section{SARAN}

Penelitian ini merupakan hasil identifikasi senyawa dengan metode analisis $G C-M S$, sehingga perlu dilakukan uji in vitro dan in vivo untuk memperjelas aktivitas senyawa-senyawa tersebut.

\section{DAFTAR PUSTAKA}

Al-Rubaye, Abeer Fauzi, Imad Hadi Hameed2, Mohanad Jawad Kadhim. A Review: Uses of Gas Chromatography-Mass Spectrometry (GC-MS) Technique for Analysis of Bioactive Natural Compounds of Some Plants. 2017. International Journal of Toxicological and Pharmacological Research 2017; 9(1); 81-85. University of Babylon: Iraq.

Budiasih, K.S. 2017. Kajian Potensi Farmakologis Bunga Telang (Clitoria ternatea). Yogyakarta: Universitas Negeri Yogyakarta.

Chayaratanasin, Poramin., dkk. 2015. Inhibitory Effect Of Clitoria Ternatea Flower Petal Extract On Fructose-Induced Protein Glycation, And Oxidation-Dependent Damages To Albumin In Vitro. BMC Complementary and Alternative Medicine. 15:27. Research Group of Herbal Medicine for Prevention and Therapeutic of Metabolic Diseases. Chulalongkorn University: Bangkok Thailand.

Hartono, M.A., dkk. 2013. Pemanfaatan Ekstrak Bunga Telang (Clitoria ternatea, L.) sebagai Pewarna Alami Es Lilin. [Skripsi]. Fakultas Teknobiologi. Universitas Atma Jaya: Yogyakarta. 1-49.

Rubiyanto, D. 2017. Metode Kromatografi. CV Budi Utama: Yogyakarta.

Al Sanafi, A.E. 2016. Pharmacologial importance of Clitoria ternatea. IOSR Journal of Pharmacy. 6(3), 57-67.

Ezzudin, Muhammad dan Rabeta, M. S. 2018. A potential of Telang tree (Clitoria ternatea) in human health. Food Research Journal. Minden, Penang: Universiti Sains Malaysia 